\title{
Encontro da Sociedade Americana de Química em Orlando, Flórida, USA
}

Quando ouvimos falar em Orlando-Flórida, logo pensamos em diversão, aventura, heróis e muita adrenalina. Entretanto, há muito mais do que parques de diversão em Orlando, como por exemplo um centro de convenções gigantesco, capaz de abrigar mais de 15 mil pessoas. Essa é a média de comparecimento em uma conferência da Sociedade Americana de Química (ACS) em nível nacional. Foi em abril último (de 7 a 11) que aconteceu o $223^{\circ}$ encontro nacional da ACS em Orlando, no centro de convenções Orange County. O fato de eu morar em Miami facilitou a minha participação nesse evento, que recebe cientistas de todo o país e do mundo também. Além dos Estados Unidos, pude ver alguns trabalhos da França, China, Coréia e Japão. Dado às dimensões da conferência, o programa é enviado pelo correio e pode ser acessado via internet, o que permite ao conferencista organizar sua agenda com antecedência. Além da apresentação de trabalhos científicos, uma exposição tecnológica ocorre simultaneamente, com mais de 290 companhias e organizações. Na segunda feira acontece o Sci-Mix, a sessão de painéis que reúne trabalhos escolhidos de várias áreas, único evento de confraternização das mais de vinte divisões científicas. Na área de polímeros existem duas divisões, Division of Polymer Chemistry e Division of Polymeric Materials: Science \& Engineering. As sessões orais neste evento incluíam temas gerais como metodologia em self assembly e novos conceitos em materiais poliméricos. Outros temas que foram bastante explorados também, não só em polímeros, incluíam aplicação de polímeros em fotônica e a utilização de filmes automontados (layer-by-layer) de polieletrólitos nas mais diversas aplicações. É notável a tendência de aplicação dos trabalhos na área biomédica, em geral a busca de modificação de superfícies para utilização de sistemas in vivo. Um exemplo interessante foi mostrado por um pesquisador da Ciba, que apresentou um trabalho no qual filmes automontados de polieletrólitos e enzimas são empregados na modificação de lentes de contato, o que eles chamaram de "lentes hidrofílicas". A maior vantagem desse sistema é a biocampatibilidade do produto devido à natureza do recobrimento da lentes. Outros temas também abordados foram polímeros condutores, polímeros organometálicos e química e engenharia de poliolefinas.

A conferência da ACS é mesmo uma aventura científica, que demanda muita disposição para enfrentar as jornadas diárias, em busca de novidades e conhecimento. Os heróis no centro de convenções Orange County, diferente da Disney World, eram gente de verdade, orientadores, estudantes e pós-docs, cujas idéias são apreciadas e levadas muito a sério pela sociedade americana.

Notícia elaborada por Sarita V. Mello, Post-Doctoral Associate, University of Miami, Florida, USA. 